\title{
Effect of organic and inorganic sources on the distribution of different fractions of potassium in vertisol
}

\section{N.R. MAIRAN AND A.S. DHAWAN}

Article Chronicle :

Received :

16.10.2015;

Revised :

20.10.2015;

Accepted :

05.11 .2015
ABSTRACT : A field experiment was conducted at Dryland Research Station,Vasantrao Naik Marathwada Krishi Vidyapeeth, Parbhani during 2003-04 and 2004-05 in Vertisol with application of organics and inorganics sources of nutrients under different cropping system viz., soybean- pigeonpea and sorghum- pigeonpea. After these two crop cycles, the added potassium was found to be converted to various potassium fractions. Among the different fractions, maximum potassium was found in the form of total potassium followed by lattice potassium, non-exchangeable $\mathrm{K}$, exchangeable $\mathrm{K}$, Water soluble $\mathrm{K}$. The Water soluble $\mathrm{K}$ and exchangeable $\mathrm{K}$ in soil decreased with the age of crop due to their utilization by crop for its nutrition. The relationship as simple and multiple regressions between available $\mathrm{K}$ and different $\mathrm{K}$ fractions was interdependent to each other.

HOW TO CITE THIS ARTICLE : Mairan, N.R. and Dhawan, A.S. (2015). Effect of organic and inorganic sources on the distribution of different fractions of potassium in vertisol. Asian J. Environ. Sci., 10(2): 113-119.

Key Words :

Potassium

fractions,

Relationship,

Cropping

systems

Author for correspondence :

\section{N.R. MAIRAN}

Department of Soil

Science and Agricultural

Chemistry, Vasantrao

Naik Marathwada

Krishi Vidyapeeth, PARBHANI (M.S.) INDIA

See end of the article for

Coopted authors' 